\title{
Physical exercise and academic performance
}

\begin{abstract}
The practice of physical exercise has been classically associated with improvements in metabolic functions such as cardiovascular, ventilator, hormonal, etc. However, in the last decades, it has increased the number of studies that relate physical exercise, cognitive functions and academic performance. In recent years, many studies have reported the relationship between physical exercise and grades obtained at primary, secondary and university levels, which may be influenced by the improvement of attention, work memory and executive functions after the increase of blood vessels and neurogenesis influenced by the practice of physical exercise.
\end{abstract}

Keywords: Physical exercise, aerobic exercise, academic performance, cognitive functions
Volume I Issue 4 - 2017

\author{
Fernando Maureira Cid,' Hernán Díaz \\ Muñoz ${ }^{2}$ \\ 'Escuela de Educación en Ciencias del Movimiento y Deportes, \\ Universidad Católica Silva Henríquez, Chile \\ ${ }^{2}$ Department of Industrial Engineering, Faculty of Engineering, \\ University of Santiago de Chile, Chile
}

\author{
Correspondence: Fernando Maureira Cid, Escuela de \\ Educación en Ciencias del Movimiento y Deportes, Universidad \\ Católica Silva Henríquez, Chile,
}

Email maureirafernando@yahoo.es

Received: May 26, 2017| Published: September 27, 2017

\section{Introduction}

The continuous practice of physical exercise has been shown to have positive effects on various metabolic functions such as cardiovascular capacity, pulmonary ventilation, secretion of certain hormones, platelets function and coagulation, renal function, etc., ${ }^{1,2}$ as well as being associated with a decrease in chronic non-contagious diseases such as diabetes, cardiovascular diseases and respiratory diseases. ${ }^{3,4}$ But in the last decades, physical exercise has been linked to improvements in brain structures, which leads to an improvement in cognitive functions such as attention, memory, planning, inhibition, etc. ${ }^{5}$ This last situation has allowed establishing a relation between the practice of physical exercise and the academic performance. ${ }^{6-8}$

The academic performance corresponds to a system that measures the achievements and the construction of knowledge in the students. In many educational systems this concept is often associated with a rating scale (1 to $10,1.0$ to $7.0,0$ to 100 , etc.) with an approval value (for example, on a scale of 1 to 10, a value of 6 indicates the student's approval). Artunduaga ${ }^{9}$ establishes the importance of demographic variables (age, sex, work, etc.), cognitive (abilities, intelligence, etc.) and attitudinal variables (interest, motivation, self-concept, etc.). For its part, Barahona ${ }^{10}$ shows that variables such as gender, conformity to studied area and qualifications in verbal and mathematical tests, are excellent predictors of general academic performance. Other authors such as Pérez \& Castejón ${ }^{11}$ establish that verbal self-concept and verbal fluency are the best predictors of language performance, whereas numerical aptitude and mathematical self-concept better predict mathematical outcomes. Finally, Tejedor ${ }^{12}$ establishes gender, age, personality, intelligence, motivation, study habits, teaching methods, evaluation strategies, parental studies, etc., as representing important elements that can determine academic performance.

Most models that account for factors influencing qualifications include cognitive variables such as attention, memory and executive functions. ${ }^{13,14}$ In addition, numerous studies establish the relationship between practicing physical exercise and cognitive function improvement. ${ }^{15-18}$ This fact allows establishing a relation between the practice of physical exercise, the improvement of cognitive functions and the increase of the academic performance of the students.

\section{Discussion}

A study by Dubuc et al. ${ }^{19}$ evaluated 100 women (24.4 \pm 4.6 years) of the University of Quebec in Canada, showing a relationship between the academic results and $\mathrm{VO}_{2} \max (\mathrm{r}=0.32 ; \mathrm{P}=0.001)$. Another study by Anderson \& Good $^{20}$ studied the relationship between BMI, problem solving and qualifications of 279 college students $(73 \%$ female and $27 \%$ male). The results show a negative and low relationship between BMI and student qualifications averages $(r=-0.190, p=0.001)$ and a positive relationship between problem solving and university performance $(r=0.357, p=0.001)$. The authors propose the relationship between healthy body weight and academic achievement.

On the other hand, an investigation of Beck et al..$^{21}$ applied a 6-week intervention to 165 Danish children $(7,5 \pm 0,02$ years old) where he associated motor work with performance in mathematics. The control group received conventional math classes, the intervention group 1 (G1) received a math class integrated with gross motor movements and intervention group $2(\mathrm{G} 2)$ received an integrated math class with fine motor movements. The children were examined before, immediately after and 8 weeks after the intervention. It was used a standardized mathematical test to evaluate mathematical performance. The results show an improvement in the results of the math test immediately after the intervention, with better results for G1. In addition, there were no significant differences between the pre-intervention measurement and the 8 -weeks later measurement.

A study by Kao et al. ${ }^{22}$ analyzed the relationship between aerobic capacity, muscle capacity, working memory and academic performance in 79 children between 9 and 11 years old. The results show that, after controlling for socio-demographic variables, there is a relation between aerobic capacity and working memory and performance in mathematics. In the same way the muscular capacity is related to the working memory. Other research ${ }^{23}$ studying children aged 6 to 8 years, showed that moderate to vigorous physical activity was related to reading fluency $(\mathrm{p}<0.05)$ and better reading comprehension $(\mathrm{p}<0.05)$. A study by Esteban et al. ${ }^{24}$ with 1146 students ( $12.5 \pm 2.5$ years old) related sedentary behavior (surfing the internet, listening to music and sitting down quietly) associate negatively with academic achievement ( $p>0.05$ ) Maureira et al. ${ }^{8}$ evaluated 309 secondary school students, 
analyzing the relationship between physical exercise and language, math, history and science, finding a positive relationship only with mathematics, possibly due to the common elements of this discipline with the motor execution.

Contrary to previous results, a study by Esteban et al. ${ }^{25}$ with 1780 subjects between 6 and 18 years of age $(48.5 \%$ female and $51.5 \%$ female) did not show a relation between physical activities and the academic performance. The authors conclude that the time devoted to physical activity is not sufficient in time and intensity to provoke substantial changes in the school environment.

The studies carried out in recent years provide more and more evidence of the beneficial effects of physical exercise on brain functions, which have an impact on an improvement in academic performance. This improvement is usually associated with the development of new cerebral blood vessels, increased synaptic density, increased glia and neurogenesis. ${ }^{26,27}$

\section{Conclusion}

Recent studies report the positive relationship between physical exercise practice and academic performance of primary, secondary and university students. The sedentarism seems to be a risk factor for the cognitive functions, which represent fundamental elements for the correct school performance. These data give account of the physical exercise as a new tool for cognitive improvement and gives the responsibility to the professional of the physical activity, not only be aware of the improvement of the physical qualities and motor capacities, but also of an active and concomitant role in the academic improvement of the students.

Future research is needed to establish more precisely what type of physical activities or exercises are most appropriate and when is the ideal time to stimulate brain functions, in addition to applying interventions in different school contexts and different populations. ${ }^{28}$

\section{Acknowledgements}

None.

\section{Conflict of interest}

Author declares there is no conflict of interest in publishing the article.

\section{References}

1. López J, Fernández A. Fisiología del ejercicio. Médica Panamericana. Spain; 2006. p. 1005.

2. Wilmore J, Costill D. Fisiología del esfuerzo físico y del deporte. Paidotribo. Spain; 2007. p. 575.

3. Gami AS, Witt BJ, Howard DE, et al. Metabolic syndrome and risk of incident cardiovascular events and death: a systematic review and metaanalysis of longitudinal studies. J Am Coll Cardiol. 2007;49(4):403-414

4. Romero C. El síndrome metabólico. Rev Med Urug. 2006;22(2):108-121.

5. Maureira F. Principios de neureducación física. Editorial Académica Espanola. Spain; 2014. p. 356.

6. Dwyer T, Sallis J, Blizzard L, et al. Relation of academic performance physical activity and fitness in children. Pediatric Exercise Science. 2001;13:225-237.

7. Fredericks C, Kokot S, Krog S. Using a developmental movement programme to enhance academic skills in grade 1 learners. S Afr J Res Sport Phys Educ Recreation. 2006;28(1):29-42.
8. Maureira F, Díaz I, Foos P, et al. Relación de la práctica de actividad física y el rendimiento académico en escolares de Santiago de Chile. Revista de Ciencias de la Actividad Física UCM. 2014;15(1):43-50.

9. Artunduaga M. Variables que influyen en el rendimiento académico en la Universidad. Tesis de doctorado. Universidad Complutense de Madrid, Spain; 2008. p. 17.

10. Barahona P. Factores determinantes del rendimiento académico de los estudiantes de la Universidad de Atacama. Estudios Pedagógicos. 2014;40(1):25-39.

11. Pérez P, Castejón J. Capacidad predictiva de las variables cognitivo-motivacionales sobre el rendimiento académico. REME. 2008;11(28):1-13.

12. Tejedor F. Los alumnos de la Universidad de Salamanca. Características y rendimiento academic, Ediciones Universidad de Salamanca, Spain; 1998.

13. Parra CG, Gómez E, Ostrosky F. Relación entre las funciones cognitivas y el rendimiento académico en ninos. Revista Neuropsicología, Neuropsiquiatría y Neurociencias. 2009;9(1):41-54.

14. López M. Rendimiento académico: su relación con la memoria de trabajo. Actualidades Investigativas en Educación. 2013;13(3):1-19.

15. Angevaren M, Aufdemkampe G, Verhaar H, et al. Physical activity and enhanced Fitness to improve cognitive function in older people without know cognitive impairment. Cochrane Database Syst Rev. 2008;3:CD005381

16. Maureira F, Henríquez F, Carvajal D, et al. Efectos del ejercicio físico agudo sobre la memoria visual de corto plazo en estudiantes universitarios. Revista Ciencias de la Actividad Física UCM. 2015;16(1):29-35.

17. Auley E, Szabo AN, Mailey EL, et al. Non-exercise cardiorespiratory fitness: associations with brain structure, cognition and memory complaints in older adults. Ment Health Phys Act. 2011;4(1):5-11.

18. Pesce C, Crova C, Cereatti L, et al. Physical activity and metal performance in preadolescents: effects of acute exercise o free-recall memory. Mental Health and Physical Activity. 2009;2(1):16-22.

19. Dubuc M, Aubertin M, Karelis A. Relationship between Academic Performance with Physical, Psychosocial, Lifestyle and Sociodemographic Factors in Female Undergraduate Students. Int J Prev Med. 2017;13(8):22.

20. Anderson A, Good D. Increased body weight affects academic performance in university students. Prev Med Rep. 2016;28(5):220-223.

21. Beck M, Lind R, Geertsen S, et al. Motor-Enriched Learning Activities Can Improve Mathematical Performance in Preadolescent Children. Front Hum Neurosci. 2016;23(10):645.

22. Kao S, Westfall D, Parks AC, et al. Muscular and Aerobic Fitness, Working Memory and Academic Achievement in Children. Med Sci Sports Exerc. 2017;49(3):500-508.

23. Haapala EA, Väisto J, Lintu N, et al. Physical activity and sedentary time in relation to academic achievement in children. J Sci Med Sport. 2017;20(6):583-589.

24. Esteban I, Martínez D, Sallis J, et al. Objectively measured and selfreported leisure-time sedentary behavior and academic performance in youth: The UP\&DOWN Study. Prev Med. 2015;77:106-111.

25. Esteban I, Martínez D, Garcia L, et al. Objectively Measured Physical Activity During Physical Education and School Recess and Their Associations With Academic Performance in Youth: The UP\&DOWN Study. J Phys Act Health. 2017;14(4):275-282.

26. Chaddock L, Erickson K, Prakash R, et al. A neuroimaging investigation of the association between aerobic fitness, hippocampal volume and memory performance in preadolescent children. Brain Res. 2010;1358:172-183. 
27. Cotman C, Berchtold N. Exercise: a behavioral intervention to enhance brain health and plasticity. Trends Neuroscience. 2002;25(6):295-301.
28. Kramer A \& Erickson K. Capitalizing on cortical plasticity: influence of physical activity on cognition and brain function. Trends Cogn Sci. 2007;11(8):342-348. 